that it is unscientific-unphilosophical-to state an hypothesis or formulate a theory, and much more so to make a categorical stalement, when no antecedent facts are given nor any subsequent verification attempted. Thus, Mr. Cockerell asks the question, "Why is it that plants growing on exposed sea-shores have a tendency to lie upon the ground or otherwise to evade the violence of the winds" (my italics)? Now, what evidence has he to bring forward that the purpose of lying down is to evade the violence of the winds? So far, it is nothing more than his private opinion-an a priori assumption. It is true that he adds a reason, but it is also drawn from his own consciousness, and not from nature : "When a plant is growing among others, it has to compete with them in raising itself into conspicuousness." But do not dwarf plants ever compete? My experience of the South Downs, where plants are for the most part considerably dwarfed, is that the struggle between them is a severe one. Yet their flowers and foliage are fully exposed to sunlight and insects, as well as to severe gales of wind. $\mathrm{Mr}$. Cockerell also appears to forget that what is true for one plant is true for another, and each must try to overtop all the others.

I would venture to warn our younger naturalists most earnestly against this facilis descensus of a priori reasoning without facts or verification. It has been the bane of metaphysics; and when a scientific man like Dr. Weismann puts forth, in the name of science, most deplorable illustrations of it in his late attempt to apply his theory to plants, it is time that some one should venture to protest.

In reply to his request, I would refer Mr. Cockerell to M. Verlot's pamphlet "Sur la Production et la Fixation des Variétés," in which he describes his method of creating and fixing dwarf plants by sowing seed late in the season. Also to M. Roujou's experiments in selecting the smallest seeds of plants (Fourn. d'Hist. Nat. de Bordeaux et du Sud-Ouest, I884). Mr. McNab also raised dwarf rhododendrons by using pollen from the smallest stamens. Want of space forbids me adding more on the subject. GEORGE HeNsLow.

\section{The Natural Selection of Indian Corn.}

IN a former letter I had occasion to mention that Zea mais varies in its period of maturing, and that at certain altitudes and latitudes, only some of the varieties (i.e. the early maturing) are able to mature at all, the rest being absolutely eliminated by natural selection in a single generation. A few days ago $I$ received, through the kindness of Mr. James Fletcher, the new (1891) Report on Experimental Farms for I890, published by the Canadian Government, in which are numerous statistics of experimental planting in different parts of the Dominion. On p. 296, Mr. T. A. Sharpe gives an account of the result of planting twenty-nine different varieties of Indian corn at Agassiz, British Columbia, which perhaps deserves notice, as illustrating the above-mentioned facts in a particularly clear way. Of the varieties planted (all exposed to the same kind of environment), the majority did not form any ears at all. Some formed very small ears, and others reached various stages of maturity, but only a very few actually matured.

For example, I will quote some of them :-

No. r. Moore's Early Concord, corn matured, one of the best.

No. 3. Early Adams, corn matured to glazing stage.

No. 6. Mitchell's Extra Early White Flint, produced some matured ears.

No. II. Marblehead Sugar, matured corn, ears very small.

No. 12. Narraganset, sweet, corn did not fill to tips of cob.

No. 14. Chester Co. Mammoth, no corn formed.

No. 21. Golden Dent, no ears formed.

T. D. A. COCKERELL.

3 Fairfax Road, Bedford Park, Chiswick, W., May 10.

The Soaring of Birds.

IT seems a great pity that the simpler form of this questionwherein birds soaring steadily rise, in a gentle breeze, over a large plain-is needlessly complicated by the flight of sea-birds over waves.

We shall get the solution best by taling the former and less complicated case, wherein the pelicans, adjutants, cyrus, vultures, \&c., slowly rise, by soaring alone, to great heights, under conditions where up-rushes of air are quite out of the question.
Upper Asam is a dead level, some 60 miles wide by 200 long, and over this area, wherein these birds rise by soaring alone, the air-drift is almost invariably from north-north-east, or else south-west, and at about 5 to ro miles an hour. They do not seem to rise in a dead calm, nor yet in stormy weather, and I take it the desideratum is a slow air-drift, or gentle steary breeze.

That there are no up-rushes of air, I have fairly good proof in the small tufts of cotton, from the Bombyx malabaricum, which cross the field of my telescope when examining the Noga Hills at 10 to 20 or 30 miles; these are always beautifully horizontal at elevations from 200 to 2000 feet, coming from the plains and hills north-east of us.

So that out here there is no complication of the case by vertical movements of the air, as at sea. The question is not how large birds sustain themselves (without flapping their wings) in a wind, when there are rising and falling and strata of "different velocities"; but how large birds like the cyrus, adjutant, pelican, and vulture can rise from 300 to 3000 feet, in a steady breeze, without flapping their wings.

It is not mere flotation; they have to raise 20 or 30 pounds some 2000 feet, in addition to what the albatross does.

Surely this is the major question, at once simpler to see, and more difficult to answer.

In NATURE (vol. xxiii. p. I0) I drew attention to this, and sent a small diagram, to show how $I$ thought it was done. I have frequently observed the phenomena since, and see no reason to modify my views,

Firstly, these large birds do not soar in a dead calm, or a storm, or during high winds. They prefer a steady breeze.

Secondly, they rise from the ground, by flapping the wings, and continue this till they are roo or 200 feet up, and then begin to soar, in right or left hand spirals, IOo or 200 yards across. At each lap they rise ro or 20 feet, and make as many yards leeway, drifting slowly with the wind, and continue thus to rise until out of sight above.

With a good telescope a bird can be easily followed after a little practice, and the only motion which can be seen is slight and occasional movement of the tail, in steering.

The legs (of the waders) are extended at full length behind, the neck thrown on the back, and beak projecting over the

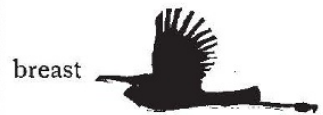

The tips of the primary wing-

feathers are always well separated in different planes,
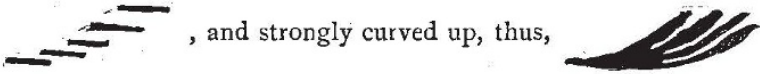

evidently under great strain.

The lifting power is evidently applied to them mainly, and the plane of the outspread wings is not horizontal, but forms part of an obtuse, inverted cone, as though a little centrifugal force was implicated.

The speed of the bird is always greater than the breeze, and the resistance is unequal on opposite sides of the loop of the spiral; least when it travels with the breeze, and greatest when on the opposite half, meeting it.

It seems to me the solution is that, when going with the wind, the bird gathers momentum by going down a slight incline, and when it turns and meets the breeze, this extra momentum is used in lifting the bird and carrying it over a shorter course. Thus it starts the next lap at a slightly higher level, but some 20 yards to leeward. Variation of the speed of the wind at different levels is here quite out of the question; the bird, too, keeps to its steady spiral, and as steadily ascends at each lap.

I feel sure that Prof. Tait, Sir W. Thomson, and Lord Rayleigh will find the case I state a more profitable one to study than the erratic flight or floating of sea-birds. The telescope I use to watch and follow these birds when soaring is a $3^{\circ} 5^{\prime \prime} \mathrm{O}$.G. power 50 , with long tripod legs, and on a mattrass below I find no difficulty in keeping a bird in the field, if at rooo feet up. My own idea is that all these birds go up there to sleep or doze. Sibsagar, Asam, March 30.

S. E. PEAL.

NO. I I 25 , VOL. 44] 